\title{
Comparative morphology of the postpharyngeal gland in the Philanthinae (Hymenoptera, Crabronidae) and the evolution of an antimicrobial brood protection mechanism
}

\author{
Katharina Weiss', Erhard Strohm', Martin Kaltenpoth ${ }^{2,3}$ and Gudrun Herzner ${ }^{1 *}$
}

\begin{abstract}
Background: Hymenoptera that mass-provision their offspring have evolved elaborate antimicrobial strategies to ward off fungal infestation of the highly nutritive larval food. Females of the Afro-European Philanthus triangulum and the South American Trachypus elongatus (Crabronidae, Philanthinae) embalm their prey, paralyzed bees, with a secretion from a complex postpharyngeal gland (PPG). This coating consists of mainly unsaturated hydrocarbons and reduces water accumulation on the prey's surface, thus rendering it unfavorable for fungal growth. Here we (1) investigated whether a North American Philanthus species also employs prey embalming and (2) assessed the occurrence and morphology of a PPG among females of the subfamily Philanthinae in order to elucidate the evolution of prey embalming as an antimicrobial strategy.

Results: We provide clear evidence that females of the North American Philanthus gibbosus possess large PPGs and embalm their prey. The comparative analyses of 26 species from six genera of the Philanthinae, using histological methods and 3D-reconstructions, revealed pronounced differences in gland morphology within the subfamily. A formal statistical analysis based on defined characters of the glands confirmed that while all members of the derived tribe Philanthini have large and complex PPGs, species of the two more basal tribes, Cercerini and Aphilanthopsini, possess simple and comparatively small glands. According to an ancestral state reconstruction, the complex PPG most likely evolved in the last common ancestor of the Philanthini, thus representing an autapomorphy of this tribe.

Conclusion: Prey embalming, as described for P. triangulum and T. elongatus, and now also for $P$. gibbosus, most probably requires a complex PPG. Hence, the morphology and size of the PPG may allow for inferences about the origin and distribution of the prey embalming behavior within the Philanthinae. Based on our results, we suggest that prey embalming has evolved as an antimicrobial strategy in and is restricted to the tribe Philanthini, which seems to face exceptional threats with regard to fungal infestations of their larval provisions.
\end{abstract}

Keywords: Postpharyngeal gland, 3D reconstruction, Comparative morphology, Prey preservation, Antimicrobial, Antifungal, Crabronidae, Philanthinae, Beewolves

\footnotetext{
* Correspondence: Gudrun.Herzner@ur.de

'Evolutionary Ecology Group, Institute of Zoology, University of Regensburg,

Universitätsstr. 31, 93053 Regensburg, Germany

Full list of author information is available at the end of the article
} 


\section{Background}

Microorganisms pose serious threats to insects both as pathogens [1-3] and food competitors [4-6]. Many solitary wasps rely on paralyzed arthropod prey as food for their developing offspring [7]. To protect these nutrientrich resources from harmful microorganisms, wasps have evolved elaborate antimicrobial strategies (e.g. [8-14]). Especially in species that mass-provision their brood with paralyzed prey, it is crucial that the stored resources stay consumable throughout the feeding period of the larva [15].

The European beewolf Philanthus triangulum (Fabricius) (Hymenoptera, Crabronidae, Philanthinae) shows a remarkable antimicrobial defense mechanism. Females of this digger wasp prey exclusively on honeybee workers, Apis mellifera, as provisions for their offspring (see e.g. $[16,17])$. The paralyzed bees are stored in subterranean brood cells under warm and humid conditions, which impose a high risk of fungal infestation on the larval provisions (e.g. [10]). As a countermeasure, females extensively lick the surface of their prey prior to oviposition [10], thereby applying large amounts of a lipid secretion to the bee's cuticle [18, 19], a behavior termed 'embalming' in the following. Since this secretion contains predominantly unsaturated hydrocarbons (HCs) $[19,20]$, embalming not only increases the total amount of HCs but also the proportion of unsaturated HCs on the prey's surface $[18,19]$. The coating of unsaturated HCs changes the physicochemical properties of the bees' epicuticle, resulting in a reduction of water condensation. The resulting change in microclimate retards fungal growth, thus reducing the decomposition of the larval resources and increasing larval survival $[10,18,21]$.

The source of the embalming secretion is the postpharyngeal gland (PPG) [19, 20, 22], a cephalic gland which has long been thought to be restricted to ants where it is mainly involved in the generation and maintenance of the colony odor ( e.g. [23-26], for a review of other functions see [27]). In female $P$. triangulum, the PPG consists of two large reservoirs originating dorsally from the pharynx at the proximal end of the hypopharyngeal plate and extending laterally anterior to the brain (hereafter referred to as 'upper part of the PPG') [22]. Each reservoir of this upper part of the gland consists of a main root with numerous 'fingers' branching off, resulting in an overall glove-like shape of the gland [22]. Additionally, a smaller unpaired sac-like evagination extends ventrally from the pharynx (hereafter referred to as 'lower part of the PPG') [22]. The walls of all parts of the PPG are formed by a monolayered epithelium with apical hairs that reach into the lumen of the gland. The content of the gland is most probably not synthesized by the epithelial cells but is rather sequestered from the hemolymph via the enlarged gland surface $[22,28]$.
Besides $P$. triangulum, a PPG has also been described for two species of the genus Trachypus [29] (which group within Philanthus according to a recent phylogenetic analysis [30]). The morphology of the PPGs of both Trachypus elongatus and Trachypus boharti closely resembles the PPG of $P$. triangulum [29]. In both Trachypus species, the PPG also contains mostly $\mathrm{HCs}$, and T. elongatus has been shown to embalm its prey, stingless bees, with the secretion of its PPG [29].

Both species for which prey embalming has so far been described, $P$. triangulum and T. elongatus, belong to the tribe Philanthini within the subfamily Philanthinae $[30,31]$. The Philanthinae consist of eight genera separated into three tribes [31]: The Philanthini, comprising (Philanthus + Trachypus) + Philanthinus, represent a sister group to the other two tribes, the Cercerini, comprising (Cerceris + Eucerceris) + Pseudoscolia, and the Aphilanthopsini comprising Clypeadon +Aphilanthops [31]. All philanthine wasps share basic life-history traits, including hunting and nesting behavior. Females build subterranean nests and mass-provision brood cells with paralyzed insects (Hymenoptera or Coleoptera) as food for the developing larvae (e.g. [32-36]). Thus, all Philanthinae may face similar selection pressures with regard to the protection of their larval provisions and their offspring against detrimental microbes. As a consequence, all of these species likely either employ prey embalming with PPG secretion or some other prey preservation mechanism.

In the present study, we aim to shed light on the evolution of the prey embalming behavior and the associated complex PPG and ask whether these traits are common to all Philanthinae or have arisen in only some lineages. First, in order to broaden our knowledge about the distribution of this antimicrobial mechanism within the Philanthinae, we analyzed whether the North American Philanthus gibbosus (Fabricius), shows prey embalming. Second, we investigated 26 species belonging to six genera representing all three tribes of the Philanthinae with regard to the occurrence and morphology of the PPG as well as another head gland that could be involved in prey preservation, the mandibular gland (MG). We provide a comparative morphological analysis based on characters obtained by histological investigations and 3D-reconstructions of the head glands. Our analysis revealed pronounced differences in the morphology of the PPG between the different tribes of the Philanthinae, which may allow for inferences about the origin and distribution of the prey embalming behavior within this subfamily.

\section{Methods}

Prey embalming in Philanthus gibbosus

A detailed description of the methodology of this section is given in Additional file 1. Briefly, P. gibbosus females 
were reared in observation cages as described earlier for P. triangulum [37] and supplied with halictid bees (Hymenoptera, Halictidae) as prey. Owing to the limited availability of halictid bees, several different species had to be used. To investigate whether $P$. gibbosus females embalm their prey with HCs from their PPG, paralyzed bees were removed from $P$. gibbosus brood cells (hereafter referred to as 'provisioned bees', $N=6$ ) and their cuticular HCs were analyzed by gas chromatography/mass spectrometry (GC/MS). For comparison, halictid bees which had no contact to the beewolves (hereafter referred to as 'control bees', $N=9$ ) and heads of field-caught $P$. gibbosus females $(N=4)$ were analyzed accordingly. As both provisioned and control bees comprised a number of different halictid species, a molecular identification of the species was conducted [see Additional file 1: Table S1]. For the chemical analysis, whole bees as well as $P$. gibbosus heads were extracted, an internal standard was added for quantification and aliquots were analyzed by GC/MS. $N$-alkanes were identified by comparison of their retention times and mass spectra to synthetic references. Linear retention indices (LRIs) for all other substances were calculated in relation to the $n$-alkanes [38], and alkenes were identified by their LRIs and mass spectra as described in Strohm et al. [20]. The structure of the unsaturated ketone nonacosen6-one was tentatively assigned by its mass spectrum as described previously [29]. Absolute amounts of components were calculated by use of the internal standard and compared between provisioned and control bees by a Mann-Whitney $U$ test. Relative amounts were calculated by standardizing the total peak area of a sample to $100 \%$. The proportions of unsaturated compounds were arcsine-transformed and compared between provisioned and control bees using a $t$ test; in addition, we compared the relative amounts of individual HCs. All tests were performed using the statistics software package PAST (Version 2.08b) [39]. Unless otherwise stated, values given are means \pm standard deviation (SD).

\section{Comparative morphology of head glands \\ Specimens}

Females of 26 species and subspecies belonging to six genera covering the three tribes of the crabronid subfamily Philanthinae were included in the morphological analysis (Table 1). The tribe Philanthini was represented by eight Philanthus species from Europe and South Africa, nine Philanthus species from North America, four Trachypus species from South America, and one Philanthinus species from Turkey. The Aphilanthopsini were represented by one Clypeadon and one Aphilanthops species from North America, and the Cercerini by two European Cerceris species.
Table 1 Philanthine species included in the comparative morphological study

\begin{tabular}{|c|c|c|c|c|}
\hline Species & $\mathrm{N}$ & Country & Fixative & $3 \mathrm{D}$ \\
\hline Aphilanthops frigidus & 2 & USA & AAF & yes \\
\hline Clypeadon laticinctus & 3 & USA & AAF & yes \\
\hline Cerceris arenaria & 2 & Germany & Bouin & yes \\
\hline Cerceris quinquefasciata & 3 & Germany & AAF & yes \\
\hline Philanthinus quattuordecimpunctatus & 3 & Turkey & $\mathrm{EtOH}$ & yes \\
\hline Trachypus flavidus & 1 & Brazil & $\mathrm{EtOH}$ & yes \\
\hline Trachypus elongatus & 3 & Brazil & AAF & yes \\
\hline Trachypus patagonensis & 1 & Brazil & AAF & no \\
\hline Trachypus boharti & 3 & Brazil & AAF & yes \\
\hline Philanthus venustus & 1 & Turkey & AAF & yes \\
\hline Philanthus coronatus & 1 & Germany & Bouin & yes \\
\hline Philanthus triangulum & 3 & Germany & Bouin & no \\
\hline Philanthus triangulum diadema & 3 & South Africa & AAF & yes \\
\hline Philanthus capensis & 1 & South Africa & AAF & yes \\
\hline Philanthus loefflingi & 3 & South Africa & AAF & yes \\
\hline Philanthus rugosus & 3 & South Africa & AAF & yes \\
\hline Philanthus melanderi & 1 & South Africa & AAF & yes \\
\hline Philanthus bicinctus & 1 & USA & Bouin & yes \\
\hline Philanthus ventilabris & 2 & USA & AAF & yes \\
\hline Philanthus crabroniformis & 1 & USA & AAF & no \\
\hline Philanthus multimaculatus & 1 & USA & AAF & yes \\
\hline Philanthus barbiger & 2 & USA & AAF & yes \\
\hline Philanthus gibbosus & 3 & USA & Bouin & yes \\
\hline Philanthus albopilosus & 2 & USA & Bouin & yes \\
\hline Philanthus psyche & 2 & USA & AAF & yes \\
\hline Philanthus pulcher & 1 & USA & AAF & no \\
\hline
\end{tabular}

List of species included in the comparative morphological study of head glands of female Philanthinae, including information on the number of specimens examined $(\mathrm{N})$, collection site of the species (Country), the fixative agent used for the histological preparation (Fixative; AAF = formalin-ethanolacetic acid; Bouin = alcoholic Bouin; $\mathrm{EtOH}=100 \%$ ethanol), and whether a 3Dreconstruction of the head glands was conducted (3D; yes $=3 \mathrm{D}$-reconstruction; no $=$ glands not reconstructed)

\section{Histology}

Wasps were cold anesthetized and decapitated. The heads were fixed using different fixing agents (Table 1). For large heads, both compound eyes were laterally cut off after fixation using sharp razor blades to facilitate the infiltration of the embedding medium. Heads were then thoroughly rinsed in $70 \%$ or (in case of formalin-ethanol-acetic acid fixation) $80 \%$ ethanol, dehydrated in a graded ethanol series and propylene oxide, and embedded in Epon 812 according the suppliers instructions (Polysciences Europe $\mathrm{GmbH}$, Eppelheim, Germany). Sagittal semithin sections $(4 \mu \mathrm{m})$ were cut with a microtome (Reichert Ultracut; Leica Microsystems AG, Wetzlar, Germany) 
equipped with a diamond knife and subsequently stained with toluidine blue [40]. The resulting series of histological sections were used for histological investigation of the head glands by light microscopy (Zeiss Axiophot 2; Carl Zeiss Microscopy GmbH, Jena, Germany) using bright field and differential interference contrast settings and for 3D-reconstructions of the head glands.

\section{D-reconstruction}

To visualize the overall morphology of head glands and facilitate their comparison, 3D-reconstructions of the head glands were conducted for 22 of the 26 investigated species. Even though for one Trachypus and three Philanthus species no complete series of sections were available (Table 1), the histological sections were sufficient to allow for the determination of gland characters. For 3D-reconstruction, continuous series of semithin sections of one individual per species were photographed using a digital microscope camera (Olympus DP20; Olympus, Japan) attached to a light microscope (Zeiss Axiophot 2; Carl Zeiss Microscopy GmbH, Jena, Germany). The digitalized sections were automatically aligned with regard to each other using the software package TrakEM2 [41] for the open source image processing software Fiji [42], and the alignment was subsequently corrected manually where necessary. The relevant structures within the head capsule were then marked as 3Dobjects in TrakEM2 by manually outlining them in each picture of a series. Finally, 3D-reconstructions were calculated and visualized using Fiji's 3D-viewer plug-in [43].

\section{Statistical analysis of gland morphology}

After a comprehensive examination of both semithin histological sections and 3D-reconstructions of the head glands of female Philanthinae, we defined eight morphological characters of the PPG for a comparative statistical analysis. As the PPG might not be the only possible source of the embalming secretion (see Discussion), we also included five morphological characters of the MG, the only other head gland of female Philanthinae with a reservoir of considerable size. The 13 characters of the two glands comprised information on gland structure, as well as their overall shape and location within the head capsule. For each character, the different character states were categorized and numerically coded for statistical analysis. Detailed descriptions of all characters and the coding of their different states are given in Additional file 1 . In short, the defined characters were: (1) overall structure of the PPG, (2) shape of the upper part of the PPG, (3) number of lobes of the upper part of the PPG, (4) number of openings of the upper part of the PPG to the pharynx, (5) relative size of the PPG in relation to the head capsule, (6) structure of the inner walls of the PPG, (7) shape of the lower part of the PPG, (8) number of openings of the lower part of the PPG to the pharynx, (9) overall structure of the MG, (10) relative size of the MG in relation to the head capsule, (11) branching of the MG, (12) structure of the inner walls of the MG, (13) association of the MG with gland cells.

To formally assess the pattern of PPG morphology among the species we used characters 1 through 8 of the data matrix [see Additional file 1: Table S2] to conduct a hierarchical cluster analysis for ordination with the statistics software package PAST (Version 2.08b) [39]. In a second analysis, the morphological characters of the MG were included [see Additional file 1: Table S2, characters 9 through 13] in order to consider a possible impact of MG morphology on the clustering of species. Bray-Curtis indices were used as similarity measures and 'unweighted pair-group averages' as the clustering algorithm; the number of bootstrap replicates was set to 10,000 .

To trace the evolution of PPG overall shape, the character which shows the most striking differences among the Philanthinae and most probably reflects differences in function of the PPG (see Results und Discussion), we conducted an ancestral state reconstruction [44] based on the molecular phylogeny of the Philanthinae [30]. The ancestral state reconstruction was performed using both maximum parsimony (unordered character states) and maximum likelihood (ML) approaches in Mesquite (Version 3.04) [45]. The ML analysis was performed using the Markov k-state 1 parameter model, in which any particular character change is considered equally probable, as the model of evolution. As outgroup we included the only apoid wasp outside the Philanthinae currently known to possess a PPG, the cockroach wasp Ampulex compressa (Fabricius) (Hymenoptera, Ampulicidae) [46]. In A. compressa the PPG is located behind the brain (as opposed to is location anterior to the brain in the Philanthinae), but it shows the typical structure (monolayered epithelium, hairs), ultrastructure of the epithelial cells, and chemistry (HCs) [46] that can be found in both, the Philanthinae [20, 22, 29] and ants [23-27]. With reference to a recent concept of homology [47], which proposes that the position of homologous characters can be variable among species, we tentatively assume homology between the PPGs of $A$. compressa and the Philanthinae.

\section{Results}

\section{Prey embalming in Philanthus gibbosus}

To establish whether P. gibbosus females embalm their prey, the chemical profiles of $P$. gibbosus females' heads, surfaces of provisioned bees taken from $P$. gibbosus brood cells, and those of control bees caught in the field were compared. In head extracts of $P$. gibbosus females, we detected 19 compounds, including 17 alkanes, alkenes, 
and alkadienes with chain lengths ranging from 23 to 31 carbon atoms, as well as the unsaturated long-chain ketone nonacosen-6-one, and one unidentified compound [see Additional file 1: Table S3]. The extracts were dominated by unsaturated HCs (mean proportion $87 \pm 2 \%$ ), with the main compounds being pentacosene $(24 \pm 6 \%)$, heptacosene $(31 \pm 3 \%)$, nonacosene $(44 \pm 3 \%)$, and hentriacontene $(3 \pm 0.8 \%)$, as well as the alkane pentacosane $(30 \pm 3 \%)$. Among the minor compounds was the alkene octacosene. The extracts of control bees contained 56 substances, of which 32 were identified as alkanes, alkenes, and alkadienes; the remaining 24 compounds were not further identified [see Additional file 1: Table S3]. The samples of provisioned bees contained a total of $45 \mathrm{sub}-$ stances, including 27 alkanes, alkenes, and alkadienes, as well as the ketone nonacosen-6-one, and 16 unidentified substances [see Additional file 1: Table S3].

The two minor compounds octacosene and nonacosen6-one occurred only in extracts of $P$. gibbosus females and provisioned bees, but not in those of control bees [see Additional file 1: Table S3]. Moreover, the proportions of the major compounds of $P$. gibbosus females (sum of isomers if more than one occurred) were significantly higher on provisioned than on control bees (Fig. 1): heptacosene + heptacosadiene ( $21 \pm 6 \%$ vs. $2 \pm 5 \%$; $t$ test: $\mathrm{t}=5.93, p<0.0001)$, nonacosene $(25 \pm$ $7 \%$ vs. $1 \pm 1 \%$; $t$ test: $\mathrm{t}=9.4, p<0.0001)$, and hentriacontene + hentriacontadiene $(3 \pm 2 \%$ vs. $0.2 \pm 0.4 \% ; t$ test: $\mathrm{t}=$ 5.39, $p=0.0001$ ).

Most importantly, provisioned bees carried a considerably larger proportion of unsaturated HCs than controls (55 $\pm 16 \%$ vs. $31 \pm 26 \% ; t$ test: $\mathrm{t}=2.3, p=0.04$; Fig. 2 ). The total amount of cuticular substances on provisioned bees was, on average, twice as high as on control bees;

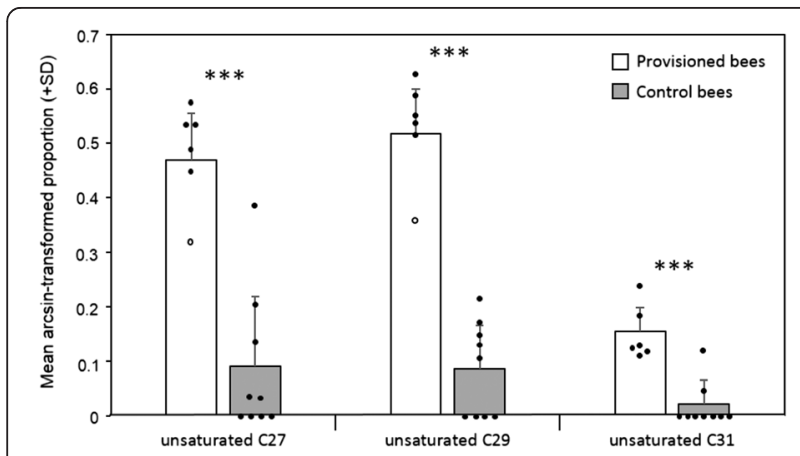

Fig. 1 Major hydrocarbons of P. gibbosus on provisioned and control bees. Mean arcsine-transformed proportion (+ standard deviation, SD) of heptacosene + heptacosadiene (unsaturated C27), nonacosene (unsaturated C29), and hentriacontene + hentriacontadiene (unsaturated (31) in extracts of provisioned bees taken from $P$. gibbosus brood cells (white bars, $N=6$ ) and control bees which had no contact to the beewolves (grey bars, $N=9$ ); closed circles show individual data points (open circles indicate outliers). Asterisks indicate a significance level of $p \leq 0.001$ according to $t$ tests (including outliers)

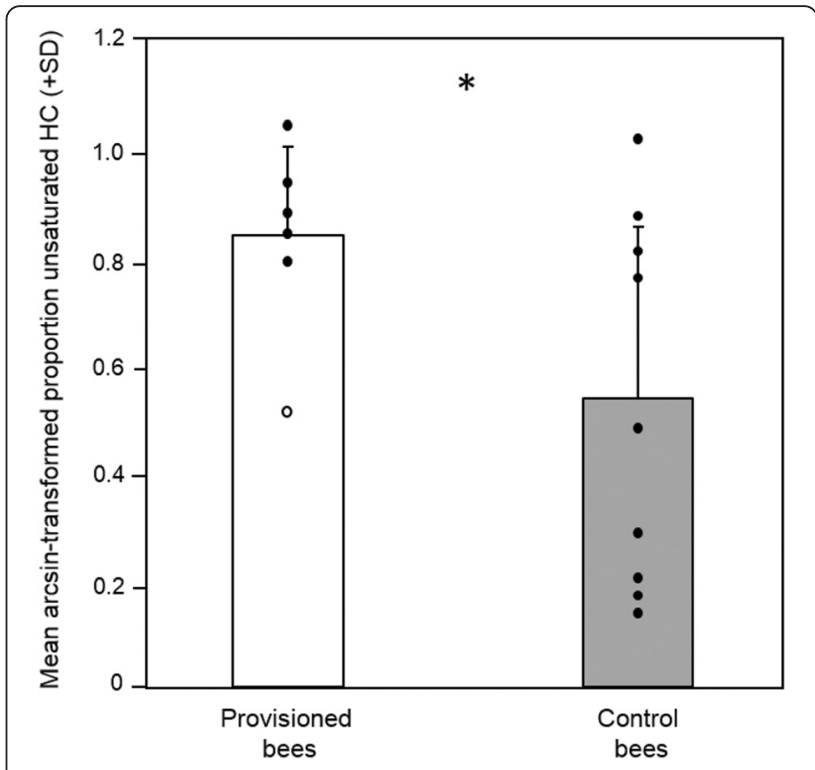

Fig. 2 Proportion of unsaturated hydrocarbons on provisioned and control bees. Arcsine-transformed proportion (+ standard deviation,

$\mathrm{SD}$ ) of unsaturated hydrocarbons ( $\mathrm{HCS}$ ) in extracts of provisioned bees $(N=6)$ taken from $P$. gibbosus brood cells and control bees $(\mathrm{N}=9)$ which had no contact to the beewolves; closed circles show individual data points (open circle indicates outlier). Asterisk indicates a significance level of $p<0.05$ according to a $t$ test (including outlier)

however, this difference was statistically not significant $(8.7 \pm 6.5 \mu \mathrm{g}$ vs. $4.1 \pm 3.9 \mu \mathrm{g}$; Mann-Whitney $U$ test, $\mathrm{N}$ provisioned bees $=6, \mathrm{~N}$ controls $=9, U=12$, exact $p=$ 0.09).

\section{Comparative morphology of head glands}

Females of all 26 investigated philanthine species possessed evaginations of the pharynx, originating posterior to the hypopharyngeal plate and, thus, qualifying as PPGs (Fig. 3, Philanthus barbiger). In all species, the wall of the PPG was formed by a monolayered epithelium, whose cells bore hair-like structures on their inner (apical) sides (Fig. 4). The density of these hairs varied between species [see Additional file 1: Table S2, character 6] and was generally found to decline from the proximal part near the pharynx to the distal parts of the lateral branches of the gland. Besides the paired upper part of the PPG, most species also possessed a smaller sac-like lower part of the gland originating ventrally from the pharynx [see Additional file 1: Table S2, character 1].

The 3D-reconstructions revealed two distinct 'types' of overall PPG morphology: In all Aphilanthopsini (Aphilanthops frigidus, Clypeadon laticinctus) and Cercerini (Cerceris arenaria, Cerceris quinquefasciata) each side of both upper and lower part of the PPG consisted of a simple tube-shaped evagination of the pharynx, with the glands of Aphilanthops and Clypeadon 


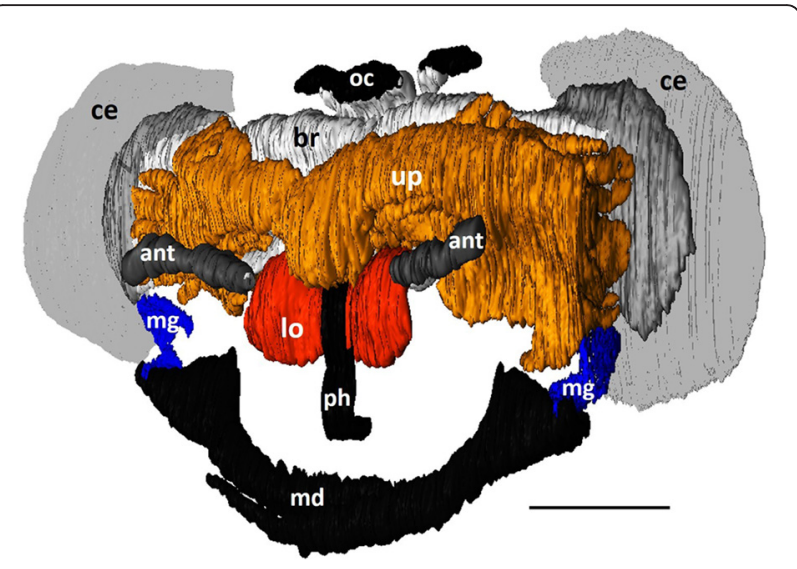

Fig. 3 3D-reconstruction of the head structures of a female Philanthus barbiger. The upper reservoir of the PPG (orange) is located in front of the brain (light grey) and extends laterally towards the compound eyes (grey), the sac-like lower reservoir of the gland (red) originates ventrally from the pharynx (black). The small MG reservoirs (blue) are located laterally on both sides of the head capsule, opening at the mandibular base. Abbreviations: ant, antenna; br, brain; ce, compound eye; lo, lower part of PPG; md, mandibles; mg, mandibular gland reservoir; oc, ocelli; ph, pharynx; up upper part of PPG. Scale bar $=0.5 \mathrm{~mm}$

being somewhat stouter than those of Cerceris (Fig. 5a-d). Except for $A$. frigidus, where the two sides of the upper part of the PPG shared one opening, each PPG-tube had a separate opening to the pharynx [see Additional file 1: Table S2, characters 4 and 8].

By contrast, in the 17 investigated species and subspecies of the tribe Philanthini (Philanthus, Trachypus, and Philanthinus) the upper part of the PPG was comparatively larger and showed a glove-or comb-like overall structure with multiple 'fingers' branching off from a common root (Fig. $5 \mathrm{e}-\mathrm{x}$ ). The number of these 'fingers' varied among species, ranging from seven to more than

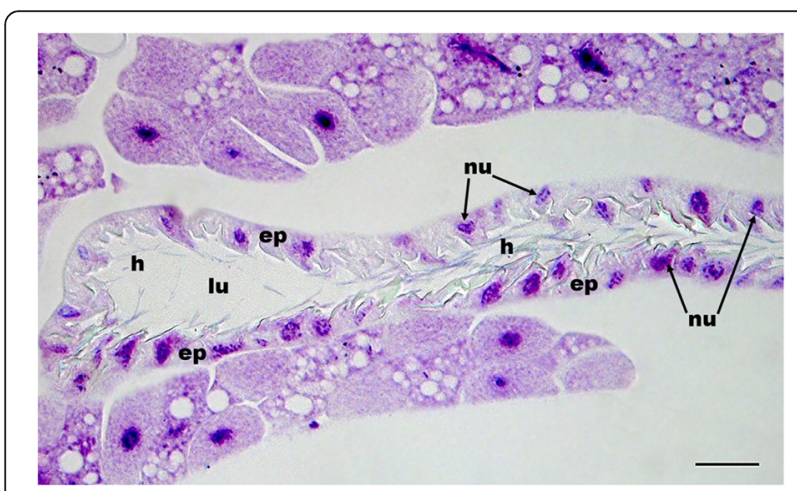

Fig. 4 Histological section of the postpharyngeal gland (PPG) of a female Philanthus rugosus. The epithelial cells of the upper reservoir of the PPG bear cuticular hairs reaching into the lumen of the gland. Abbreviations: ep, epithelial cells; h, hairs; lu, lumen of the upper PPG reservoir; nu, nuclei of epithelial cells. Scale bar $=25 \mu \mathrm{m}$
15 per side [see Additional file 1: Table S2, character 3]. The left and right part of the upper PPG had either separate openings to the pharynx or shared a common opening [see Additional file 1: Table S2, character 4]. The lateral extension of the upper part of the PPG varied among species, ranging from $55 \%$ to $76 \%$ of the head capsule width [see Additional file 1: Table S2, character 5]. Two of the investigated Trachypus species, $T$. flavidus and T. boharti, lacked the lower part of the PPG (Fig. $5 \mathrm{f}$ and h). In the other species of the Philanthini, the lower part of the PPG consisted of an unpaired saclike evagination that was considerably smaller than the upper part of the gland.

In comparison to the PPG, the differences in the overall morphology of the MG among species were smaller. The MG of all investigated Philanthinae consisted of a pair of lateral and (relative to the PPG) small, unbranched sac-like reservoirs that opened dorsally at the base of the mandibles (Fig. 3) [see Additional file 1: Table S2, characters 9 and 11]. The walls of the MG were formed by a monolayered epithelium, which did not bear any conspicuous surface structures in any species (Fig. 6) [see Additional file 1: Table S2, character 12]. The size of the MG, however, varied somewhat among species (Fig. 5) [see Additional file 1: Table S2, character 10]. In the two investigated Cerceris species, the six Philanthus species $P$. triangulum, $P$. triangulum diadema, P. gibbosus, Philanthus melanderi, Philanthus coronatus, and Philanthus albopilosus, as well as in T. boharti and T. flavidus the MG reservoir was associated with class III gland cells (classification according to Noirot and Quennedey [48]; Fig. 6), which were identified by their conspicuous end apparatuses and conducting canals. Other cells surrounding the MG in other species might constitute class I gland cells [48]; however, these cells could not unambiguously be identified as secretory cells with the light-microscopic methods applied.

The 13 morphological characters defined for the PPG and MG are summarized in the data matrix displayed in Table S2 [see Additional file 1]. A hierarchical cluster analysis using the eight characters defined for the PPG (Table S2, characters 1-8) formally confirmed the results obtained by the histological examination and 3Dreconstructions of the PPGs (Fig. 7). The first bifurcation of the dendrogram separated all species of Philanthini, possessing big glove-shaped PPGs, from both Cercerini and Aphilanthopsini, with simple tube-shaped PPGs. Within the Philanthini, the second bifurcation separated $T$. flavidus and T. boharti, which do not possess the lower sac-like evagination of the PPG, from all other Philanthini. The congeneric $T$. patagonensis and $T$. elongatus, however, clustered deeply within the other Philanthini. Generally, no obvious grouping of the species within a tribe could be observed based on PPG 

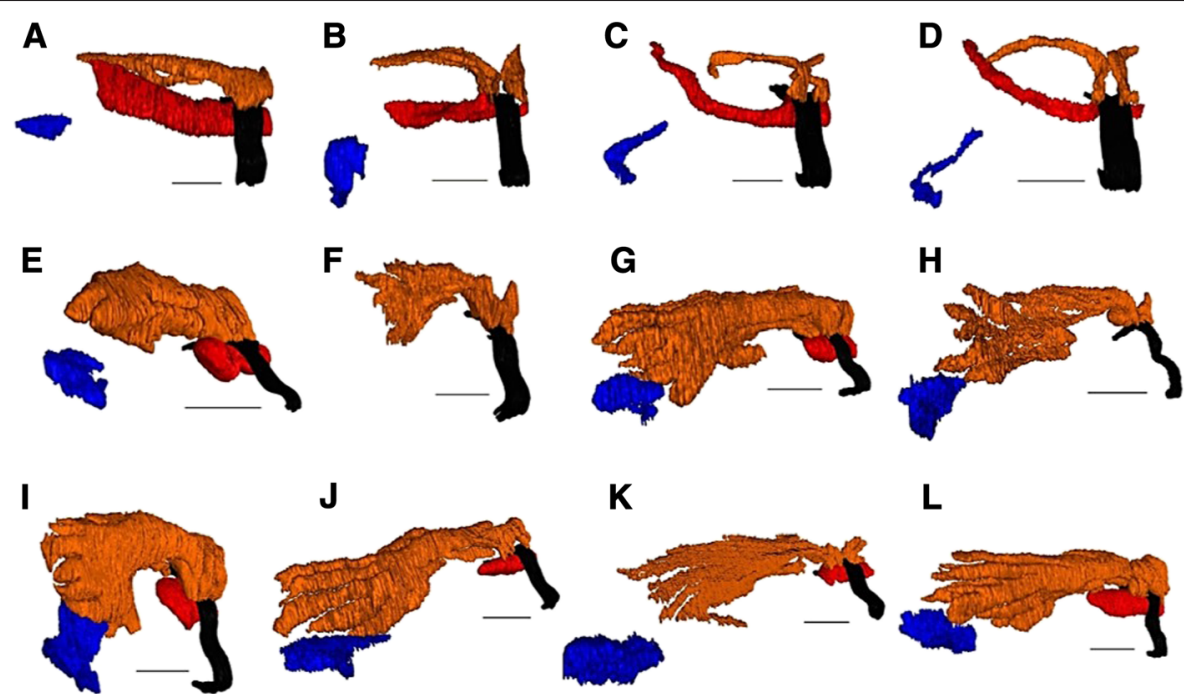

$\mathbf{L}$
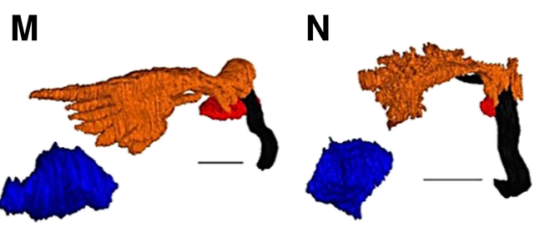

0
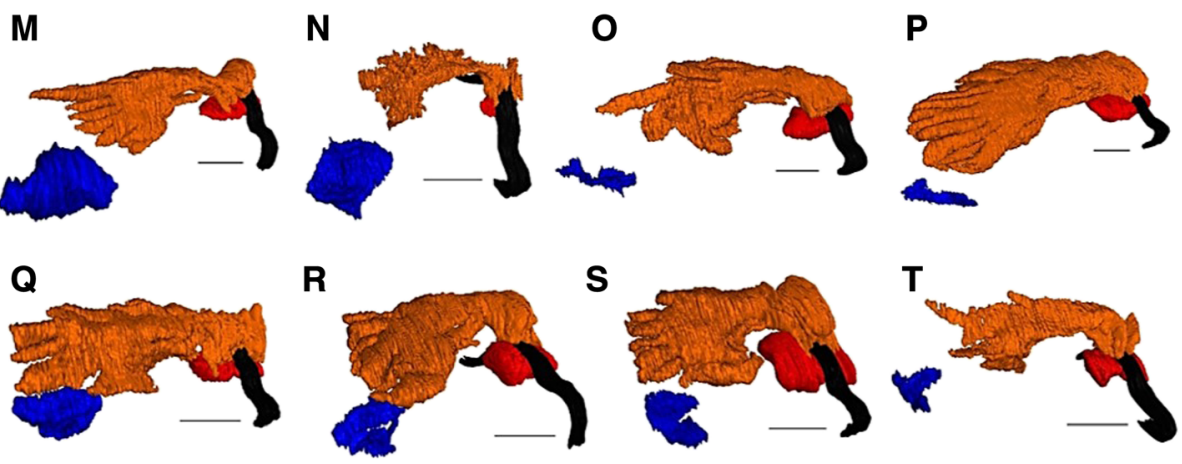

S
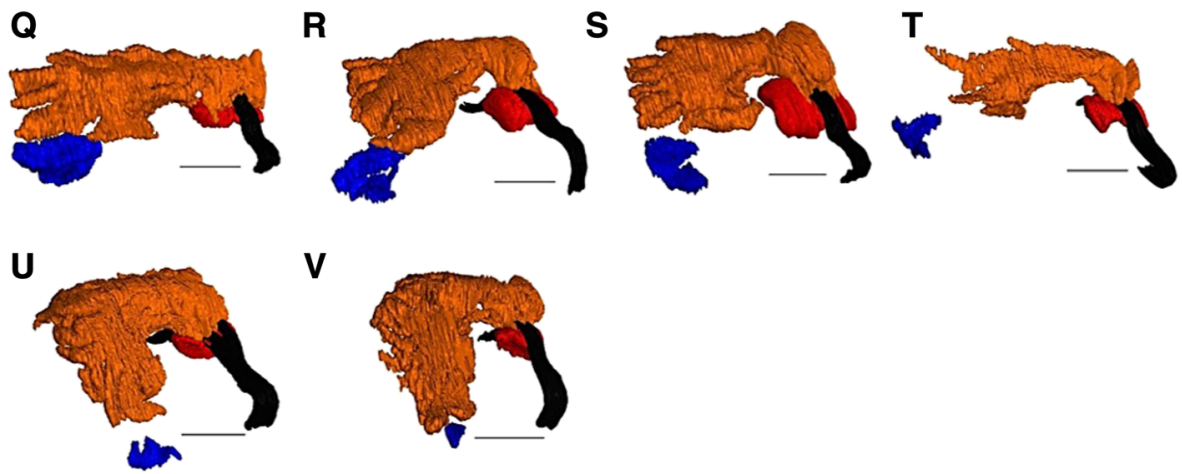

V

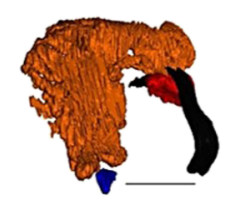

Fig. 5 3D-reconstructions of the head glands of female Philanthinae. The postpharyngeal gland (PPG) is shown in orange and red; the mandibular gland (MG) is shown in blue. Note that for each species only the right part of the head capsule is shown. a Aphilanthops frigidus; b Clypeadon laticinctus; c Cerceris arenaria; $\mathbf{d}$ Cerceris quinquefasciata; e Philanthinus quattuordecimpunctatus; $\mathbf{f}$ Trachypus flavidus (note that for this species the MG could not be reconstructed based on the available serial histological sections); $\mathbf{g}$ Trachypus elongatus; h Trachypus boharti; i Philanthus venustus; j Philanthus triangulum diadema; k Philanthus capensis; I Philanthus loefflingi; m Philanthus rugosus; $\mathbf{n}$ Philanthus melanderi; o Philanthus coronatus; $\mathbf{p}$ Philanthus bicinctus; q Philanthus ventilabris; $\mathbf{r}$ Philanthus multimaculatus; s Philanthus barbiger; $\mathbf{t}$ Philanthus gibbosus; u Philanthus albopilosus; v Philanthus psyche. Color code: orange, upper part of the PPG; red, lower part of the PPG; blue, MG; black, pharynx. Scale bars $=0.25 \mathrm{~mm}$

morphology. Moreover, most nodes were supported by only low bootstrap values. The inclusion of the data on MG morphology altered the location of single species within the Philanthini, but did not change the basic results obtained by the analysis of the PPG morphology alone [see Additional file 1: Figure S1].

The ancestral state reconstruction showed that the simple tube-shaped PPGs of Cercerini and Aphilanthopsini most likely are the ancestral PPG 'type' in the Philanthinae (ML probability: $66 \%$ ), while the more complex glove-shaped PPG most likely evolved in the last common ancestor of the tribe Philanthini (ML probability: 96 \%) (Fig. 8).

\section{Discussion}

Prey embalming in Philanthus gibbosus

We provide clear evidence that female $P$. gibbosus, as has been described for $P$. triangulum $[10,19]$ and $T$. elongatus [29], embalm their prey with HCs from their PPG: (1) Head extracts of female P. gibbosus contained 


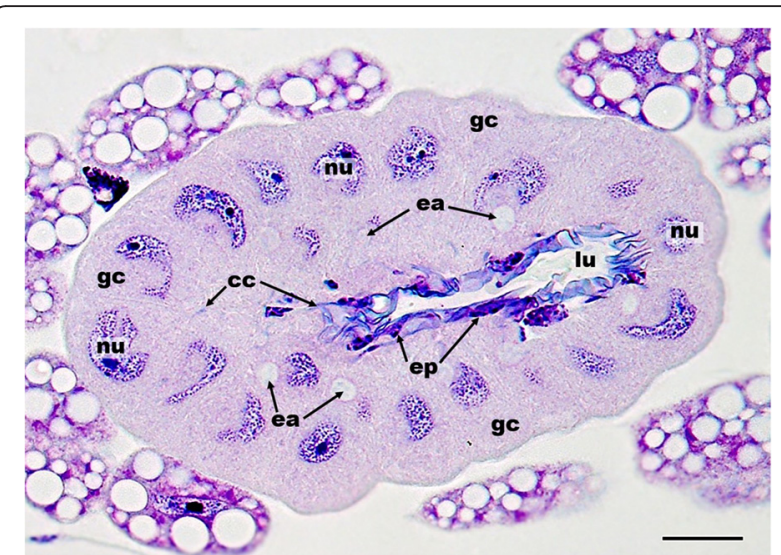

Fig. 6 Histological section of the mandibular gland (MG) of a female Cerceris quinquefasciata. The class III gland cells associated with the MG can be identified by their end apparatuses and conducting canals. Abbreviations: CC, conducting canals of class III gland cells; ep, epithelial cells of the MG reservoir; gc, class III gland cells; lu, lumen of the MG reservoir; nu, nuclei of class III gland cells. Scale bar $=25 \mu \mathrm{m}$

predominately unsaturated $\mathrm{HCs}$, like the PPGs/heads of P. triangulum [20], T. elongatus, and T. boharti [29], (2) the two components octacosene and nonacosen-6-one occurred only in samples of $P$. gibbosus heads and provisioned bees from their nests, but not on control bees, (3) the proportion of unsaturated HCs was significantly higher on provisioned bees than on control bees, and (4) this increase in the proportion of unsaturated $\mathrm{HCs}$ on provisioned bees was mostly due to an increase in the proportion of the major unsaturated HCs of P. gibbosus females.

Although the total amount of cuticular HCs was on average twice as high on provisioned bees as on control bees, the difference was not statistically significant. This may be due to the high variance in the total amount of substances within the two groups, which is partly explained by the fact that different halictid species were included in the analysis. The proportion of unsaturated compounds, on the other hand, was significantly higher on provisioned bees than on controls. Similar results (i.e. a significant difference with regard to the proportion of unsaturated $\mathrm{HCs}$ but not the total amount of HCs on provisioned vs. control bees) have been obtained for $T$. elongatus [29]. In P. triangulum, by contrast, the prey embalming results in a significant increase in both the total amount of cuticular HCs and the proportion of unsaturated components [18, 19]. As has been demonstrated in P. triangulum, it is the increased proportion of unsaturated $\mathrm{HCs}$, rather than the total amount of cuticular substances, that is crucial for the change in physicochemical properties and the resulting antimicrobial effect of prey embalming [18]. Thus, we assume that $P$. gibbosus employs a similar mechanism to protect its prey from molding as $P$. triangulum and T. elongatus.

According to a recent molecular phylogeny of the Philanthinae [30], several clades can be distinguished within the tribe Philanthini that generally coincide with their geographical distribution: The genus Philanthinus constitutes the most basal taxon of the tribe. The North American Philanthus and the South American Trachypus are sister taxa (rather than Trachypus being a separate genus, [30]) that group within the European and African Philanthus species. The fact that the three species that have yet been shown to embalm their prey (the Afro-European P. triangulum, the North American P. gibbosus and the South American T. elongatus) represent the three major clades of the Philanthini suggests that prey embalming is widespread at least within this tribe.

\section{Comparative morphology of head glands}

All three species that have been shown to employ prey embalming ( $P$. triangulum, $P$. gibbosus, and $T$. elongatus) have rather large and complex PPGs. The PPG of female $P$. triangulum contains a mean amount of $330 \mu \mathrm{g}$ of secretion (maximum: 1,400 $\mu \mathrm{g}$ ) [20], of which approximately 80 to $110 \mu \mathrm{g}$ are applied to a single prey item $[18,19]$. Even though the other two species seem to apply less secretion onto their prey, it stands to reason that a large and complex PPG is a prerequisite for prey embalming. The occurrence, morphology, and size of the PPG may hence allow for inferences about the origin and distribution of the prey embalming behavior within the subfamily Philanthinae.

All 26 philanthine species under study, including members of the hitherto not investigated genera Philanthinus, Cerceris, Clypeadon, and Aphilanthops, possess head glands that can be classified as PPGs due to their location and basic morphology. As in P. triangulum [22], T. elongatus, and T. boharti [29], the PPGs of the newly investigated species consist of paired evaginations of the pharynx anterior to the brain, constituting the upper part of the PPG, and an either paired or unpaired lower part (which is missing in some species). In all cases, the gland reservoir is bordered by a monolayered epithelium, the cells of which bear conspicuous hairs that reach into the lumen of the gland.

However, the histological investigation and 3Dreconstructions of the PPGs also revealed distinct differences in the morphology of the PPG between the tribes: The PPGs of all members of the Philanthini (Philanthus, Trachypus, and Philanthinus) are rather uniform in that they possess a voluminous upper part consisting of multiple 'fingers' branching off from a common root and the lower part comprising a considerably smaller unpaired sac-like evagination of the 


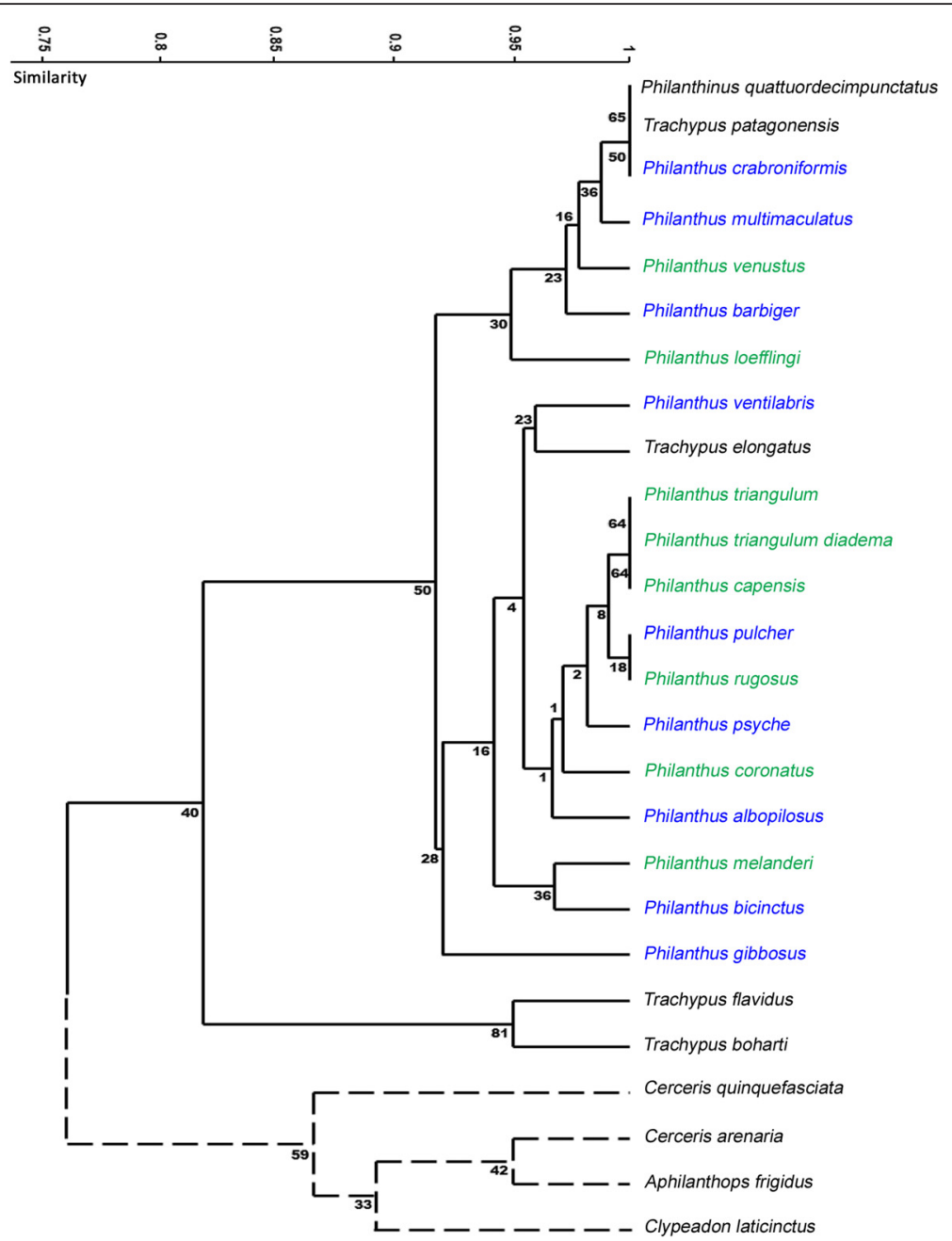

Fig. 7 Dendrogram of Philanthinae based on postpharyngeal gland morphology. Dendrogram obtained by a hierarchical cluster analysis based on eight morphological characters of the postpharyngeal gland (PPG) of female Philanthinae. Values at the nodes are bootstrap values. Solid lines indicate members of the tribe Philanthini, dashed lines indicate members of the tribes Cercerini and Aphilanthopsini. Names of European and South African Philanthus species are printed in green; names of North American Philanthus species are printed in blue. Bray-Curtis was used as similarity index; $N$ bootstrap replicates $=10,000$

pharynx, thus, closely resembling the PPGs of $P$. triangulum [22], as well as T. elongatus and T. boharti [29].

The structure of the PPG in females of the Cercerini and Aphilanthopsini differed markedly in that both upper and lower part of the PPG are paired tube-shaped evaginations of the pharynx that do not show any branching. Moreover, the glands are smaller than those found in the Philanthini.

A hierarchical cluster analysis, based on the morphological characters of the PPG, confirmed the described pattern: The first bifurcation separates the Philanthini from both Cercerini and Aphilanthopsini. Within the Philanthini, however, PPG morphology does not mirror the phylogenetic and phylogeographic relationships (e.g. North American vs. European/South African Philanthus species) within the tribe [30]. Remarkably, the shape of the PPG of female Cercerini/Aphilanthopsini resembles the PPG of the cockroach wasp A. compressa, a more basal taxon of the Apoidea [49], and the only other apoid wasp for which a PPG has been described [46]. Both sexes of $A$. compressa possess a simple PPG that consists of only one pair of small tubular evaginations of the pharynx and contains mostly HCs [46]. The ancestral state reconstruction of PPG shape using $A$. compressa as outgroup defined the simpler tubeshaped PPGs as the ancestral gland 'type' within the Philanthinae. We therefore conclude that the large complex PPGs evolved after the branching off of the Philanthini, thus representing an autapomorphy of this tribe (Fig. 9). 


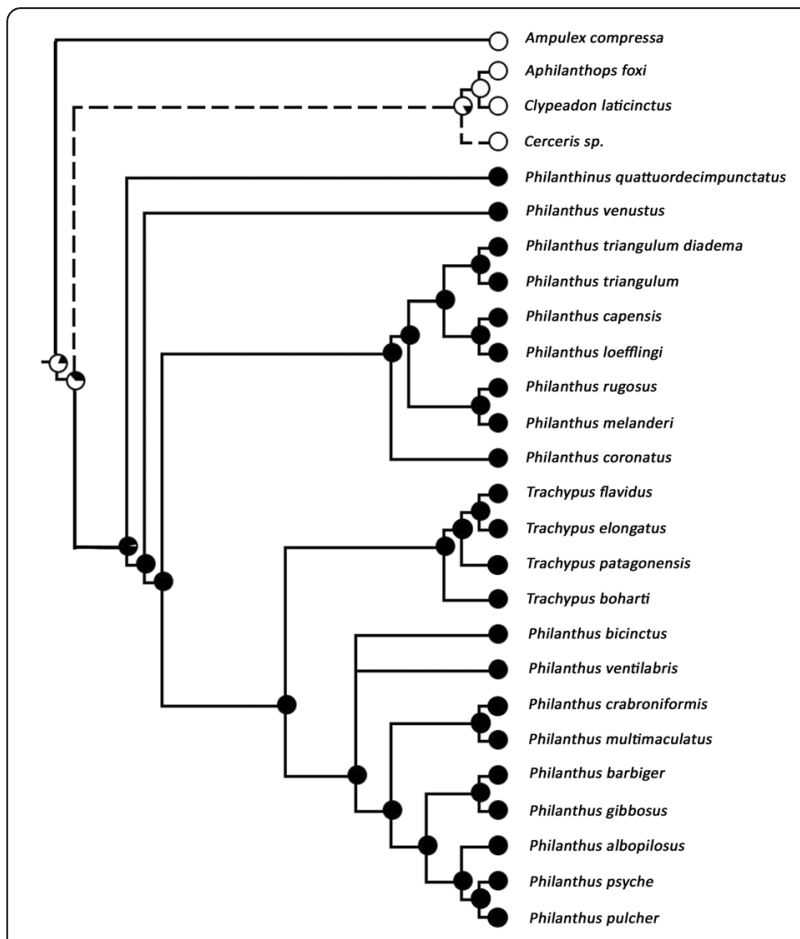

Fig. 8 Maximum likelihood (ML) ancestral state reconstruction of the overall shape of the postpharyngeal gland in the Philanthinae. The dendrogram is based on a molecular phylogeny; dashed lines indicate members of the philanthine tribes Cercerini and Aphilanthopsini. ML ancestral state reconstructions, using the Markov k-state 1 parameter model, for each node are visualized using pie charts; color code: white, simple tube-shaped PPGs; black, complex branched PPGs. As both maximum parsimony and $M L$ analyses yielded the same results, only the ML data are shown. Note that the molecular phylogeny comprised Aphilanthops foxi and one unidentified Cerceris species as representatives of the respective genera

\section{Evolution of prey embalming and complex PPGs}

It is tempting to speculate that, corresponding to the observed pattern for PPG size and morphology, the antimicrobial defense mechanism, involving the embalming of the prey with PPG secretion, as described in P. triangulum $[18,19]$, P. gibbosus (this study), and T. elongatus [29], has likewise evolved only in the Philanthini. The fact that both Cercerini and Aphilanthopsini possess only simple and comparatively smaller PPGs suggests that these species do not utilize the same prey preservation strategy as the Philanthini. Consistent with this view, female $A$. compressa do not use their PPGs for embalming their cockroach prey that serves as larval food. The comparatively small PPG of $A$. compressa has been proposed to rather function as a $\mathrm{HC}$ storage organ for other purposes [46].

There may be two possible explanations for this presumptive change in function of the PPG among basal and derived tribes of the Philanthinae. First, the Cercerini and Aphilanthopsini may use one of their two other head glands, the hypopharyngeal gland (which was present in all investigated species) or the MG, for prey embalming. The former, however, is an unlikely candidate as it lacks a reservoir (Weiss, unpublished data) and because in Hymenoptera its function seems to be restricted to the context of nutrition and digestion [50-53]. The MG of female Philanthinae, whose function is as yet unknown, does comprise a reservoir $([34,54]$, this study) and was therefore included in our study. However, our results show that the MGs of female Cercerini and Aphilanthopsini are not larger than in the Philanthini, thus providing no evidence for an enlargement of the MG of the former two tribes to compensate for the smaller volume of their PPGs to allow for prey

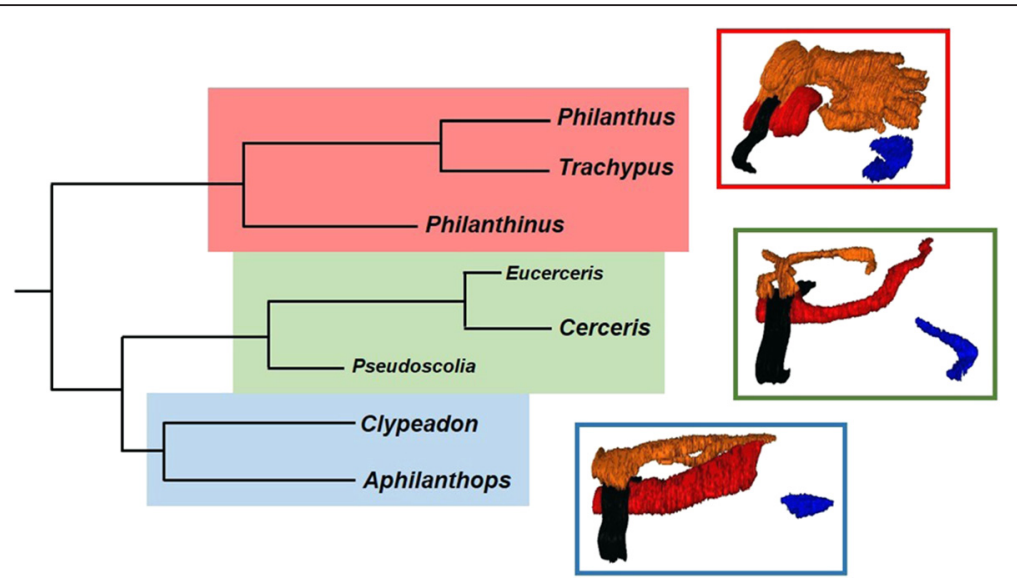

Fig. 9 Differences in gland morphology between different tribes of the Philanthinae. The morphology of the postpharyngeal gland (PPG) differs markedly between the three tribes of the subfamily Philanthinae, with all species of the Philanthini (red) possessing complex glove-shaped glands (exemplary 3D-reconstruction: Philanthus barbiger), while all investigated species of both Cercerini (green; 3D-reconstruction: Cerceris arenaria) and Aphilanthopsini (blue; 3D-reconstruction: Aphilanthops frigidus) possess simple tube-shaped glands. Note that for the Cercerini the two genera Eucerceris and Pseudoscolia (small font) have not been investigated in this study. Dendrogram modified after [31] 
embalming. Still, as the MG does contain antimicrobial compounds in other Hymenoptera (e.g. [55-57]), a role of this gland in the antimicrobial brood defense of some Philanthinae cannot be ruled out.

Second, the development of a large gland, the production of copious amounts of $\mathrm{HCs}$, and the time consuming embalming of the prey are likely to entail costs [21]. Therefore, prey embalming will only evolve under a selection regime under which its benefits outweigh these costs. The crucial factor in this regard may be the risk of fungal infestations of the larval provisions, which may depend on the microclimate in the nest as well as the susceptibility of the prey to opportunistic mold fungi.

The nest microclimate appears to be rather similar among the Philanthinae (nests in sunny sandy soil), but there are considerable differences in the prey spectrum among the Philanthinae. Members of the Philanthini provision predominantly bees and occasionally other, mostly aculeate Hymenoptera (e.g. [34]). Aphilanthopsini hunt exclusively on ants $[32,58]$. Whereas some Cerceris species prey upon bees, most Cercerini (including the two investigated in this study) rely on Coleoptera (mainly weevils and buprestids, e.g. [33]) as larval provisions. Due to the huge differences in their ecology, these diverse prey taxa may vary in their susceptibility to microbial infestation.

Ants, the prey of the Aphilanthopsini, possess an array of elaborate individual and social immune defenses involving glandular secretions $[55,57]$ and hygienic behaviors (reviewed in [59]) that might render them less susceptible to both, entomopathogenic as well as opportunistic fungi. Weevils, the prey of most Cercerini, generally feed on plants that contain secondary compounds like e.g. isoflavones, terpenes, and terpenoids [60-66]. The sequestration of these compounds, which often show antimicrobial activity $[64,66]$, might provide a certain kind of resistance to microbial attacks.

Larval provisions of the Philanthini, by comparison, might be particularly prone to microbial attack since bees are likely to obtain a range of microorganisms while foraging on flowers e.g. via contaminated pollen $[67,68]$ or by transmission from other flower visitors $[69,70]$. These microorganisms include specific or opportunistic pathogens of Hymenoptera [68, 70, 71] and, probably of more importance concerning the infestation risk of larval provisions, Ochratoxin and Aflatoxin producing mold fungi $[67,68]$. The view that the Philanthini experience exceptional threats by microbes is supported by the fact that another antimicrobial strategy, the symbiosis with antibiotics producing Streptomyces bacteria [11, 72, 73], is also restricted to the tribe Philanthini [30, 74-76].

Assuming that bees are a 'riskier' food resource than beetles and ants, it would be compelling to further investigate the Aphilanthopsini and in particular the genus Cerceris for the morphology of the PPG and the implementation of prey embalming. One might expect bee-hunting Cerceris to exhibit some kind of prey preservation behavior similar to the Philanthini, and thus also to possess larger and more complex PPGs than their beetle-hunting congeners.

\section{Conclusions}

All investigated species of the tribe Philanthini possess complex and large PPGs, whereas the investigated Aphilanthopsini and Cercerini bear comparably simple and smaller PPGs. Based on our findings it seems likely that all Philanthini employ prey embalming in a similar way as described for $P$. triangulum [10, 18, 19], P. gibbosus (this study), and T. elongatus [29]. In $P$. triangulum, prey embalming has significant positive effects on the females' reproductive success by enhancing offspring survival [21]. However, the maintenance of a complex PPG and the production of high amounts of $\mathrm{HCs}$ for prey embalming is likely to entail costs for the female [21]. The tribe Philanthini seems to have experienced stronger selection for effective prey preservation than most species of the Aphilanthopsini and Cercerini, owing to the presumably higher susceptibility to fungal infestations of the prey taxa used as larval food, so that the fitness gains eventually outweighed the costs involved in prey embalming. Future studies on the PPG and prey preservation in the Philanthinae will shed further light on the evolution of this gland and the intriguing parental care behavior of prey embalming. Our results show that the subfamily Philanthinae provides an excellent example of how even minor differences in ecology may influence the evolution of hygienic behaviors and the related morphological characters. Given the huge diversity of mass-provisioning wasps (pompilids, ampulicids, sphecids, crabronids, eumenids $[7,33])$ and their respective nesting sites and prey taxa, there are probably many more elaborate strategies of larval food preservation to be discovered.

\section{Additional file}

Additional file 1: Additional methods, additional table S1 listing
the bee species included in the chemical analyses, additional table
S2 showing the data matrix used for the cluster analysis, additional
table S3 depicting the chemical composition of the cuticular
extracts of the bees and wasps, and additional figure S1 showing
dendrogram of cluster analysis based on postpharyngeal and
mandibular gland morphology. (PDF $600 \mathrm{~kb}$ )

Competing interests

The authors declare that they have no competing interests. 


\section{Authors' contributions}

$\mathrm{ES}, \mathrm{GH}$, and KW conceived of the study. KW conducted the morphological investigations, 3D-reconstructions, and statistical analyses. GH, KW, and MK carried out the chemical analyses. KW, GH, and ES wrote the manuscript. GH and ES contributed equally to the study. All authors read and approved the final manuscript.

\section{Acknowledgements}

We thank Margot Schilling and Ulrike Helmhold for technical assistance, Kerstin Roeser-Mueller, Tobias Engl, Sabrina Köhler, Dirk Koedam, Jon Seger, Erol Yildirim, and Thomas Schmitt for help in collecting the specimens, and two anonymous reviewers for their valuable comments on an earlier version of the manuscript. Permits were issued by the nature conservation boards of KwaZulu Natal (Permit 4362/2004), Eastern Cape Province (WRO44/04WR, WRO9/04WR, WRO74/06WR, WRO75/06WR, CRO135/11CR, CRO136/11CR, CRO179/10CR, and CRO180/10CR) and Western Cape Province (001-20200026, 001-506-00001, AAA004-00053-0035, AAA004-00089-0011, AAA00400683-0035, and 0046-AAA004-00008) of South Africa, and the Brazilian Ministry of the Environment: MMA/SISBIO/22861-1. The study was supported by the Universität Bayern e. V. through a Ph. D. fellowship (K.W.), a grant of the Systematics Research Fund (SRF) jointly administered by the Council of the Linnean Society of London and the Systematics Association (G.H.; http:// www.systass.org/awards/srf.shtml), the Deutsche Forschungsgemeinschaft (German Science Foundation) (M.K., DFG KA2846/2-1), as well as the Arthur-vonGwinner-Stiftung für naturwissenschaftliche Forschungsreisen (G.H. and M.K.).

\section{Author details}

'Evolutionary Ecology Group, Institute of Zoology, University of Regensburg, Universitätsstr. 31, 93053 Regensburg, Germany. ${ }^{2}$ Insect Symbiosis Research Group, Max Planck Institute for Chemical Ecology, Hans-Knoell-Str. 8, 07745 Jena, Germany. ${ }^{3}$ Department for Evolutionary Ecology, Johannes Gutenberg University Mainz, Institute for Zoology, Johann-Joachim-Becher-Weg 13, 55128 Mainz, Germany.

Received: 30 September 2015 Accepted: 9 December 2015

Published online: 21 December 2015

\section{References}

1. Hajek AE, St Leger RJ. Interactions between fungal pathogens and insect hosts. Annu Rev Entomol. 1994;39:293-322.

2. Sikorowski PP, Lawrence AM, Inglis GD. Effects of Serratia marcescens on rearing of the tobacco budworm (Lepidoptera: Noctuidae). Am Entomol. 2001:47:51-60

3. Secil ES, Sevim A, Demirbag Z, Demir I. Isolation, characterization and virulence of bacteria from Ostrinia nubilalis (Lepidoptera: Pyralidae). Biologia. 2012;67:767-76.

4. Janzen DH. Why fruits rot, seeds mold, and meat spoils. Am Nat. 1977;111: 691-713.

5. Burkepile DE, Parker JD, Woodson CB, Mills HJ, Kubanek J, Sobecky PA, et al. Chemically mediated competition between microbes and animals: Microbes as consumers in food webs. Ecology. 2006;87:2821-31.

6. Trienens M, Keller NP, Rohlfs M. Fruit, flies and filamentous fungiexperimental analysis of animal-microbe competition using Drosophila melanogaster and Aspergillus mould as a model system. OIKOS. 2010;119: 1765-75.

7. O'Neill KM. Solitary wasps: Behavior and natural history. Ithaca: Cornell University Press; 2001.

8. Willers $\mathrm{D}$, Lehmann-Danzinger $\mathrm{H}$, Führer E. Antibacterial and antimycotic effect of a newly discovered secretion from larvae of an endoparasitic insect, Pimpla turionellae. Arch Microbiol. 1982;133:225-9.

9. Führer $\mathrm{E}$, Willers D. The anal secretions of the endoparasitic larva Pimpla turionellae: Sites of production and effects. J Insect Physiol. 1986;32:361-7.

10. Strohm E, Linsenmair KE. Females of the European beewolf preserve their honeybee prey against competing fungi. Ecol Entomol. 2001;26:198-203.

11. Kaltenpoth M, Gottler W, Herzner G, Strohm E. Symbiotic bacteria protect wasp larvae from fungal infestation. Curr Biol. 2005;15:475-9.

12. Herzner G, Schlecht A, Dollhofer V, Parzefall C, Harrar K, Kreuzer A, et al. Larvae of the parasitoid wasp Ampulex compressa sanitize their host, the American cockroach, with a blend of antimicrobials. Proc Natl Acad Sci U S A. 2013;110:1369-74.
13. Weiss K, Parzefall C, Herzner G. Multifaceted defense against antagonistic microbes in developing offspring of the parasitoid wasp Ampulex compressa (Hymenoptera, Ampulicidae). PLoS One. 2014;9.

14. Kaltenpoth M, Engl T. Defensive microbial symbionts in Hymenoptera. Funct Ecol. 2014;28:315-27.

15. Vander Wall SB. Food hoarding in animals. 1st ed. Chicago: University of Chicago Press; 1990

16. Strohm E, Linsenmair KE. Low resource availability causes extremely malebiased investment ratios in the European beewolf, Philanthus triangulum $F$ (Hymenoptera, sphecidae). Proc Royal Soc B. 1997;264:423-9.

17. Strohm E, Marliani A. The cost of parental care: Prey hunting in a digger wasp. Behav Ecol. 2002;13:52-8.

18. Herzner G, Strohm E. Fighting fungi with physics: Food wrapping by a solitary wasp prevents water condensation. Curr Biol. 2007;17:R46-7.

19. Herzner G, Schmitt T, Peschke K, Hilpert A, Strohm E. Food wrapping with the postpharyngeal gland secretion by females of the European beewolf Philanthus triangulum. J Chem Ecol. 2007;33:849-59.

20. Strohm E, Herzner G, Kaltenpoth M, Boland W, Schreier P, Geiselhardt S, et al. The chemistry of the postpharyngeal gland of female European beewolves. J Chem Ecol. 2008;34:575-83.

21. Herzner G, Engl T, Strohm E. Cryptic combat against competing microbes is a costly component of parental care in a digger wasp. Anim Behav. 2011;82:321-8.

22. Strohm E, Herzner G, Goettler W. A 'social' gland in a solitary wasp? The postpharyngeal gland of female European beewolves (Hymenoptera, Crabronidae). Arthropod Struct Dev. 2007;36:113-22.

23. Soroker V, Vienne C, Hefetz A, Nowbahari E. The postpharyngeal gland as a "Gestalt" organ for nestmate recognition in the ant Cataglyphis niger. Naturwissenschaften. 1994;81:510-3.

24. Soroker V, Hefetz A, Cojocaru M, Billen J, Franke S, Francke W. Structural and chemical ontogeny of the postpharyngeal gland in the desert ant Cataglyphis niger. Physiol Entomol. 1995;20:323-9.

25. Hefetz A, Errard C, Chambris A, LeNegrate A. Postpharyngeal gland secretion as a modifier of aggressive behavior in the myrmicine ant Manica rubida. J Insect Behav. 1996:9:709-17.

26. Lenoir A, Fresneau D, Errard C, Hefetz A. Individuality and colonial identity in ants: The emergence of the social representation concept. In: Information processing in social insects. Basel: Birkhäuser Verlag; 1999. p. 219-37.

27. Eelen D, Borgesen L, Billen J. Functional morphology of the postpharyngeal gland of queens and workers of the ant Monomorium pharaonis (L.). Acta Zool. 2006:87:101-11.

28. Strohm E, Kaltenpoth M, Herzner G. Is the postpharyngeal gland of a solitary digger wasp homologous to ants? Evidence from chemistry and physiology. Insectes Soc. 2010;57:285-91.

29. Herzner G, Kaltenpoth M, Poettinger T, Weiss K, Koedam D, Kroiss J, et al. Morphology, chemistry and function of the postpharyngeal gland in the South American digger wasps Trachypus boharti and Trachypus elongatus. PLoS One. 2013:8.

30. Kaltenpoth M, Roeser-Mueller K, Koehler S, Peterson A, Nechitaylo TY, Stubblefield JW, et al. Partner choice and fidelity stabilize coevolution in a Cretaceous-age defensive symbiosis. Proc Natl Acad Sci U S A. 2014;111:6359-64.

31. Alexander BA. A cladistic analysis of the subfamily Philanthinae (Hymenoptera: Sphecidae). Syst Entomol. 1992;17:91-108.

32. Evans HE. A review of nesting behavior of digger wasps of the genus Aphilanthops, with special attention to the mechanism of prey carriage. Behaviour. 1962:19:239-60.

33. Bohart RM, Menke AS. Sphecid wasps of the world: a generic revision. 1st ed. Ithaca: University of California Press; 1976.

34. Evans HE, O' Neill KM. The natural history and behavior of North American beewolves. 1st ed. Ithaca: Cornell University Press; 1988.

35. Polidori C, Boesi R, Isola F, Andrietti F. Provisioning patterns and choice of prey in the digger wasp Cerceris arenaria (Hymenoptera: Crabronidae): The role of prey size. Eur J Entomol. 2005;102:801-4.

36. Polidori C, Federici M, Papadia C, Andrietti F. Nest sharing and provisioning activity of females of the digger wasp, Cerceris rubida (Hymenoptera, Crabronidae). Ital J Zool. 2006;73:55-65.

37. Strohm E, Linsenmair KE. Leaving the cradle-how beewolves (Philanthus triangulum F) obtain the necessary spatial information for emergence. Zoology. 1994;98:137-46.

38. Van den Dool H, Kratz PD. A generalization of the retention index system including linear temperature programmed gas-liquid partition chromatography. J Chromatogr. 1963;11:463-71. 
39. Hammer $\varnothing$, Harper DAT, Ryan PD. PAST: Paleontological statistics software package for education and data analysis. Paleontol Electron. 2001:4

40. Adam H, Czihak G. Arbeitsmethoden der makroskopischen und mikroskopischen Anatomie. 1st ed. Stuttgart: Gustav Fischer Verlag; 1964.

41. Cardona A, Saalfeld S, Schindelin J, Arganda-Carreras I, Preibisch S, Longair M, et al. TrakEM2 software for neural circuit reconstruction. PLoS One. 2012;7.

42. Schindelin J, Arganda-Carreras I, Frise E, Kaynig V, Longair M, Pietzsch T, et al. Fiji: An open-source platform for biological-image analysis. Nat Methods. 2012;9:676-82.

43. Schmid B, Schindelin J, Cardona A, Longair M, Heisenberg M. A high-level 3D visualization API for Java and ImageJ. BMC Bioinformatics. 2010;11.

44. Pagel M. Inferring the historical patterns of biological evolution. Nature. 1999:401:877-84.

45. Maddison WP, Maddison DR. Mesquite: a modular system for evolutionary analysis. Version 3.04. 2015. http://mesquiteproject.org.

46. Herzner G, Ruther J, Goller S, Schulz S, Goettler W, Strohm E. Structure, chemical composition and putative function of the postpharyngeal gland of the emerald cockroach wasp, Ampulex compressa (Hymenoptera, Ampulicidae). Zoology. 2011;114:36-45.

47. Wagner GP. Homology, genes, and evolutionary innovation. 1st ed. Princeton: Princeton University Press; 2014.

48. Noirot C, Quennedey A. Fine-structure of insect epidermal glands. Annu Rev Entomol. 1974;19:61-80.

49. Melo GAR. Phylogenetic relationships and classification of the major lineages of Apoidea (Hymenoptera), with emphasis on the Crabronid wasps. Scientific Papers Nat. Hist. Mus. Univ. Kans. 1999:14:1-55.

50. Knecht D, Kaatz HH. Patterns of larval food production by hypopharyngeal glands in adult worker honey bees. Apidologie. 1990;21:457-68.

51. Cruz-Landim C, Costa R. Structure and function of the hypopharyngeal glands of Hymenoptera: A comparative approach. J Comp Biol. 1998;3:151-63.

52. Amaral JB, Caetano FH. The hypopharyngeal gland of leaf-cutting ants (Atta sexdens rubropilosa) (Hymenoptera : Formicidae). Sociobiology. 2005;46:515-24

53. Britto F, Caetano F. Ultrastructural features of the hypopharyngeal glands in the social wasp Polistes versicolor (Hymenoptera: Vespidae). Insect Sci. 2008; 15:277-84.

54. Ågren L. Mandibular gland morphology of Cerceris rybyensis $(\mathrm{L})$, (Hymenoptera Philanthidae). Zoon. 1977;5:91-5.

55. Brough EJ. The antimicrobial activity of the mandibular gland secretion of a formicine ant, Calomyrmex sp. (Hymenoptera, Formicidae). J Invertebr Pathol. 1983;42:306-11

56. Cane JH, Gerdin S, Wife G. Mandibular gland secretions of solitary bees (Hymenoptera, Apoidea)-Potential for nest cell disinfection. J Kansas Entomol Soc. 1983:56:199-204.

57. De Lima Mendonça AD, Da Silva CE, De Mesquita FLT, Campos RD, Do Nascimento RR, Ximenes E, et al. Antimicrobial activities of components of the glandular secretions of leaf cutting ants of the genus Atta. Anton Leeuw Int J G. 2009;95:295-303.

58. Ristich SS. The host relationship of a miltogrammid fly Senotainia trilineata (VDW). Ohio Jour Sci. 1956;56:271-4

59. Cremer S, Armitage SAO, Schmid-Hempel P. Social immunity. Curr Biol. 2007;17:R693-702.

60. Zahradník J. Käfer Mittel-und Nordwesteuropas. 1st ed. Hamburg, Berlin: Parey; 1985.

61. Phillips MA, Croteau RB. Resin-based defenses in conifers. Trends Plant Sci. 1999:4:184-90

62. Kainulainen $\mathrm{P}$, Holopainen J. Concentrations of secondary compounds in Scots pine needles at different stages of decomposition. Soil Biol Biochem. 2002;34:37-42.

63. Malinowski $\mathrm{H}$, Sierpinska A. Occurrence and harmfulness of Brachyderes incanus L. (Coleoptera: Curculionidae) to young Scots pine (Pinus sylvestris L. ) trees planted on post-fire areas. Insect Pathogens and Insect Parasitic Nematodes: Melolontha. IOBC/wprs Bulletin. 2005;28:169-73.

64. Hovelstad H, Leirset I, Oyaas K, Fiksdahl A. Screening analyses of pinosylvin stilbenes, resin acids and lignans in Norwegian conifers. Molecules. 2006;11: 103-14

65. Polidori C, Boesi R, Pesarini C, Papadia C, Bevacqua S, Federici M, et al. Temporal relationship between the prey spectrum and population structure of the weevil-hunting wasp Cerceris arenaria (Hymenoptera: Crabronidae). Zool Studs. 2007:46:83-91.
66. Saviranta NM, Anttonen MJ, Von Wright A, Karjalainen RO. Red clover (Trifolium pratense L.) isoflavones: determination of concentrations by plant stage, flower colour, plant part and cultivar. J Sci Food Agr. 2008;88:125-32.

67. González G, Hinojo MJ, Mateo R, Medina A, Jiménez M. Occurrence of mycotoxin producing fungi in bee pollen. Int J Food Microbiol. 2005; 105:1-9.

68. Foley K, Fazio G, Jensen AB, Hughes WOH. The distribution of Aspergillus spp. opportunistic parasites in hives and their pathogenicity to honey bees. Vet Microbiol. 2014;169:203-10.

69. McArt SH, Koch H, Irwin RE, Adler LS. (2014). Arranging the bouquet of disease: floral traits and the transmission of plant and animal pathogens. Ecol Lett. 2014;17:624-36.

70. Goulson D, Hughes WHO. Mitigating the anthropogenic spread of bee parasites to protect wild pollinators. Biol Conserv. 2015;191:10-9.

71. Maxfield-Taylor SA, Mujic AB, Rao S. First detection of the larval chalkbrood disease pathogen Ascosphaera apis (Ascomycota: Eurotiomycetes: Ascosphaerales) in adult bumble bees. PLoS One. 2015;10, e0124868.

72. Kroiss J, Kaltenpoth M, Schneider B, Schwinger MG, Hertweck C, Maddula RK, et al. Symbiotic streptomycetes provide antibiotic combination prophylaxis for wasp offspring. Nat Chem Biol. 2010;6:261-3.

73. Koehler S, Doubsky J, Kaltenpoth M. Dynamics of symbiont-mediated antibiotic production reveal efficient long-term protection for beewolf offspring. Front Zool. 2013;10.

74. Kaltenpoth M, Goettler W, Dale C, Stubblefield JW, Herzner G, Roeser-Mueller K, et al. 'Candidatus Streptomyces philanthi', an endosymbiotic streptomycete in the antennae of Philanthus digger wasps. Int J Syst Evol Micr. 2006:56:1403-11.

75. Kaltenpoth M, Schmitt T, Polidori C, Koedam D, Strohm E. Symbiotic streptomycetes in antennal glands of the South American digger wasp genus Trachypus (Hymenoptera, Crabronidae). Physiol Entomol. 2010;35: 196-200.

76. Kaltenpoth M, Yildirim E, Guerbuez MF, Herzner G, Strohm E. Refining the roots of the beewolf-Streptomyces symbiosis: Antennal symbionts in the rare genus Philanthinus (Hymenoptera, Crabronidae). Appl Environ Microb. 2012; 78:822-7.

\section{Submit your next manuscript to BioMed Central and we will help you at every step:}

- We accept pre-submission inquiries

- Our selector tool helps you to find the most relevant journal

- We provide round the clock customer support

- Convenient online submission

- Thorough peer review

- Inclusion in PubMed and all major indexing services

- Maximum visibility for your research

Submit your manuscript at www.biomedcentral.com/submit 